\title{
Comparison of Quality and Sensory Characteristics of Spent Hen and Broiler in South Korea
}

\author{
Sol-Hee Lee and Hack-Youn Kim *iD \\ Department of Animal Resources Science, Kongju National University, Yesan-Gun 32439, Korea; \\ chzh73@naver.com \\ * Correspondence: kimhy@kongju.ac.kr; Tel.: +82-41-330-1241; Fax: +82-41-330-1249
}

check for updates

Citation: Lee, S.-H.; Kim, H.-Y. Comparison of Quality and Sensory Characteristics of Spent Hen and Broiler in South Korea. Animals 2021, 11, 2565. https://doi.org/10.3390/ ani11092565

Academic Editors: Francesca Soglia and Simona Mattioli

Received: 30 July 2021

Accepted: 27 August 2021

Published: 31 August 2021

Publisher's Note: MDPI stays neutral with regard to jurisdictional claims in published maps and institutional affiliations.

Copyright: (c) 2021 by the authors. Licensee MDPI, Basel, Switzerland. This article is an open access article distributed under the terms and conditions of the Creative Commons Attribution (CC BY) license (https:/ / creativecommons.org/licenses/by/ $4.0 /)$.

\begin{abstract}
Simple Summary: Spent hen and broiler have clear differences according to consumption methods. The $\mathrm{pH}$, color, cooking yield, water holding capacity (WHC), and shear force of carcass characteristics and the electronic nose and electronic tongue of sensory characteristics were compared in order to recruit discarded spent hens. As a result, spent hen had a lower cooking yield and WHC compared to broiler and thus presented a higher shear force. In addition, broiler showed higher umami values than spent hen in the electronic tongue. Accordingly, it is essential to use additives with a high water holding capacity to process spent hen meat.
\end{abstract}

Abstract: This study was conducted to compare the quality and sensory characteristics of spent hen and broiler in South Korea. The carcasses of spent hens and broilers that had been slaughtered $24 \mathrm{~h}$ before were used. The cooking yield and water holding capacity of broiler was significantly higher than that of spent hen $(p<0.05)$. The $\mathrm{pH}$ of broiler thigh was significantly higher than that of the other treatments $(p<0.05)$, while on the other hand spent hen breast had a lower value than other treatments $(p<0.05)$. The redness of the thigh of both types was more than that of the breast $(p<0.05)$. In contrast, the yellowness of the breast of the two types was more than that of the thigh of both types. The changes in organoleptic characteristics of broiler was higher than that of spent hen, and the aroma patterns detected using the electronic nose were markedly different in terms of the type of meat. Spent hens are generally considered to have lower consumption rates than broilers because they have a lower taste and aroma. Therefore, the results of this study suggest that processing or additives are required in the distribution method of spent hens.

Keywords: spent hen; broiler; breast; thigh; quality and sensory characteristics

\section{Introduction}

Chickens are classified into spent hen and broiler in South Korea. Spent hens refer to hens with an increased feed demand and reduced laying efficiency due to old age [1]. Because these are old spent hens that have stopped laying eggs, the meat has a high collagen content, resulting in a tough texture [2,3]. Park et al. [4] reported that spent hens have a high concentration of insoluble protein and that their meat contains tissues that are difficult to process by heating. On the other hand, broilers are bred for meat, and their meat retains its elasticity even after heating, which makes it well-suited to consumer preferences [5]. Compared to spent hen, broiler meat contains at least $20 \%$ less unsaturated fatty acids, which leads to better storage stability [6].

According to the Korean Statistical Information Service, the breeding numbers of spent hens and broilers were 70 million and 93 million, respectively, in 2019; however, the number of slaughters showed a large difference, with 200 spent hens and 70 million broilers in the same year [7]. As a result, spent hens show difficulties in terms of the consumption of spent hen at the end of their economic life cycle, and they are typically exported to other countries or sold at a cheap price [8]. On the other hand, broilers steadily increased from $9.62 \mathrm{~kg} /$ person in 2009 to $14.80 \mathrm{~kg} /$ person in 2019 [9]. As the consumption patterns 
between the two breeds are in stark contrast, it is thought to be important to understand the appropriate processing method through the analysis of the two breeds.

The analysis of the sensory properties of ingredients is important because it is related to the type of meat, genetics, and breeding [10]. As such, there is a long history of training tasting panels and conducting sensory evaluations to analyze preferences, including taste, flavor, and texture, as part of the product development cycle [11]. However, it is difficult to recruit and train people to participate in a sensory evaluation panel, and thus the application of instrumental measurements such as shear force, the electronic tongue, and the electronic nose can provide reliable data on the eating quality of food products $[12,13]$.

Although there have been several reports on spent hens and broilers, most studies have focused on the individual properties of each type of meat, rather than comparing the two types. The aim of the present study was to compare the physicochemical and sensory characteristics of the two types of meat and analyze the meat quality and manufacture of processed meat products, in order to provide basic data for future experiments on chicken meat.

\section{Materials and Methods}

\subsection{Preparation of Spent Hens and Broilers}

Spent hen was used for the 75-week-old hy-line brown breed, and broiler was used for the 4-week-old one. Refrigerated spent hen and broiler from $24 \mathrm{~h}$ after slaughter were purchased from the local slaughterhouse. Spent hens and broilers were bred at different farms depending on the species, in compliance with the National Research Council (NRC) specification standards, and were slaughtered and used at the same slaughterhouse (Chungnam, Korea). The purchased samples were placed in an ice box and transferred to a refrigerated state to conduct the experiment. The experiment was performed in a total of 3 repetitions, and the number of individuals per repetition was 15 animals. The sample was directly deboned to obtain the breast and thigh, which were stored at $5{ }^{\circ} \mathrm{C}$ until further use. All of the experimental samples did not exceed a week at any one time, and in the case of the electronic nose and electronic tongue, the samples were frozen and used.

During the trial, the slaughter of samples was carried out in a slaughterhouse licensed by the South Korea state; therefore, approval by the ethics committee was not considered necessary.

\section{2. $p H$}

Uncooked meat was homogenized with distilled water (DW) in a 1:4 ratio using Ultraturax (HMZ-20DN, 82 Pooglim Tech, Seoul, South Korea) at $6780 \times g$, and turbidity was measured using a pH meter (S220, Mettler-Toledo, Greifensee, Switzerland).

\subsection{Color}

Lean meat was cut into a form of approximately $2.0 \mathrm{~cm}$ (height) and measured using a colorimeter (CR 210, Minolta, Tokyo, Japan) using CIE L* (lightness), CIE a* (redness), and $\mathrm{CIE} \mathrm{b}^{*}$ (yellowness) values. The color experiment was tested in a total of 5 repetitions.

\subsection{Cooking Yield}

The cooking yield of the samples was measured before and after cooking. The meat was cooked for $1 \mathrm{~h}$ in a chamber set to $75^{\circ} \mathrm{C}$, and the samples were then cooled for $20 \mathrm{~min}$ at room temperature $\left(25^{\circ} \mathrm{C}\right)$. The cooking yield was calculated using the following equation:

Cooking yield $(\%)=$ weight after cooking $(\mathrm{g}) /$ weight before cooking $(\mathrm{g}) \times 100$

\subsection{Water Holding Capacity}

The water holding capacity (WHC) of chicken meat was measured using the filter paper-press method [14]. First, $0.3 \mathrm{~g}$ of meat was weighed in a filter paper (Whatman No. 2; GE Healthcare life sciences Whatman, Chicago, IL, USA) and compressed for 3 min using 
a filter-press device. After drying the filter paper with the sample in a desiccator (sensor MT-10S, MT Precision, Tokyo, Japan) for approximately 1 day, WHC was calculated using the following equation:

$$
\text { WHC }(\%)=\text { meat area }\left(\mathrm{mm}^{2}\right) / \text { exuded water area }\left(\mathrm{mm}^{2}\right) \times 100
$$

\subsection{Shear Force}

The test of the samples was measured using the method of Park et al. [14]. The shear force of the cooked meat samples was measured using a texture profile analysis instrument (TA1, Lloyd, Largo, FL, USA). The cooked meat was cut in the same direction as the muscle and measured at right angles to the direction of the muscle. The conditions of measurement were as follows: v-vlade, head speed, $2.0 \mathrm{~mm} / \mathrm{s}$; distance, $2.0 \mathrm{~mm}$; force, $5 \mathrm{~g}$; and the measured value, $\mathrm{kg}$.

\subsection{Electronic Tongue}

The E-tongue was based on the modified method of Lee et al. [15]. Eight grams of chicken meat were weighed and homogenized for $1 \mathrm{~min}$ with $32 \mathrm{~mL}$ of DW using a homogenizer (AM-5, Nissei, Anjo, Japan). The homogenate was filtered using filter paper (Whatman No. 1, GE Healthcare, Chicago, IL, USA), and the filtrate was diluted 100 times in a glass container. Changes in organoleptic characteristics were measured using an electronic tongue system (Astree 5, Alpha MOS, Toulouse, France). Seven sensors, namely CTS, NMS, AHS, PKS, SCS, ANS, and CPS, were used. AHS, NMS, and CTS indicate the sourness, umami, and saltiness sensors, respectively, while PKS, CPS, ANS, and SCS are general-purpose sensors.

\subsection{Electronic Nose}

The test of the samples was measured using the modified method of Kang et al. [16]. The principal component analysis (PCA) of the chicken meat was performed using an electronic nose system (Heracles-II-e-nose, Alpha MOS, Toulouse, France). Five grams of each ground sample were placed in vials which were then capped. The samples were incubated for $20 \mathrm{~min}$ at $80^{\circ} \mathrm{C}$ in a controlled thermostatic agitator. Subsequently, the samples in the vials were collected under the following conditions: headspace injection of $2.0 \mathrm{~mL}$, injection speed of $200 \mu \mathrm{L} / \mathrm{s}$, and injection temperature of $200^{\circ} \mathrm{C}$. MXT-5 and MXT-1701 were mounted, and the detector temperature was maintained at $260^{\circ} \mathrm{C}$ while measuring and analyzing the sample aroma pattern using PCA (Alpha MOS, Toulouse, France).

\subsection{Statistical Analysis}

Statistical analysis was conducted with the experimental results for two types of birds (spent hen and broiler) and two types of muscle (breast and thigh). The cooking yield, WHC, shear force, $\mathrm{pH}$, and color were analyzed using a mixed model in SAS (version 9.3; SAS Institute, Cary, NC, USA), and the results are expressed as mean \pm standard deviation. Significant differences $(p<0.05)$ among the mean values were determined using an analysis of variance and Duncan's multiple range test. The correlations between WHC and cooking yield and WHC and shear force were determined using the CORR function in the SAS analysis.

\section{Results and Discussion}

\section{1. $\mathrm{pH}$ and Color}

The $\mathrm{pH}$ and color of the uncooked samples of the breast and thigh of spent hens and broilers were measured (Table 1). The $\mathrm{pH}$ was significantly lower in $\mathrm{SB}(p<0.05)$ and significantly higher in BT $(p<0.05)$. Because meat shows an isoelectric $\mathrm{pH}$ of $5.2-5.6$, the positive and negative charges are close to neutral in this interval [17]. This means that there is less space to store water inside meat proteins; therefore, the WHC is lowest at 
the isoelectric point [18]. Thus, the study is thought to have affected the findings, which were that the cooking yield also decreased as the $\mathrm{pH}$ approached the isoelectric point. This is consistent with a study by Park et al. [19], in which the $\mathrm{pH}$ in the breast and thigh from chickens of different ages were compared and a higher $\mathrm{pH}$ was observed in the thigh than in the breast. In addition, the spent hen showed a significantly lower $\mathrm{pH}$ than the broiler, which is thought to be due to the decrease in the water content in the muscles with increasing age. Beak [20] et al. showed the same results as in this study, saying that the $\mathrm{pH}$ decreased as the age of the laying hen increased.

In addition to $\mathrm{pH}$, Table 1 shows the results for the color of the breast and thigh of the spent hen and broiler. Color is an important factor because it has a major, direct impact on consumers' purchasing rates and preferences [21]. Lightness was significantly higher in BT than in SB and BB, which can be explained by the higher accumulation of the blood pigment myoglobin in thigh meat than in breast meat, which has a low exercise capacity. von Lengerken et al. [22] previously reported that the majority of muscle fibers in the breast were white fibers, while the majority of muscle fibers in the thigh were red fibers. Redness was significantly higher in $\mathrm{ST}$ and $\mathrm{BT}$ than in $\mathrm{SB}$ and $\mathrm{BB}$, which was also thought to be due to myoglobin. This is similar to the results of a study by Kadioğlu et al. [23], who studied the color of spent chicken meat and reported more redness in the thigh than in the breast. Yellowness was significantly higher in the SB group than in the other groups, which was similar to the findings of Baek et al. [20], which showed that yellowness increased with age.

Table 1. Breast and thigh muscle $\mathrm{pH}$ and color in spent hens and broilers.

\begin{tabular}{cccccc}
\hline \multirow{2}{*}{ Traits } & \multicolumn{4}{c}{ Treatment $^{\mathbf{1}}$} \\
\cline { 3 - 6 } & & SB & BB & ST & BT \\
\hline \multirow{2}{*}{$\mathrm{pH}$} & $5.64 \pm 0.06^{\mathrm{c}}$ & $6.43 \pm 0.03^{\mathrm{b}}$ & $6.37 \pm 0.06^{\mathrm{b}}$ & $6.83 \pm 0.06^{\mathrm{a}}$ \\
\hline \multirow{3}{*}{ Color } & $\mathrm{CIE} \mathrm{L}^{*}$ & $55.50 \pm 0.79^{\mathrm{a}}$ & $54.63 \pm 0.19^{\mathrm{a}}$ & $50.86 \pm 0.61^{\mathrm{b}}$ & $52.94 \pm 0.38^{\mathrm{ab}}$ \\
& $\mathrm{CIE} \mathrm{a}^{*}$ & $4.27 \pm 0.46^{\mathrm{b}}$ & $5.82 \pm 0.15^{\mathrm{b}}$ & $7.23 \pm 0.22^{\mathrm{a}}$ & $8.08 \pm 0.22^{\mathrm{a}}$ \\
& $\mathrm{CIE} \mathrm{b}^{*}$ & $6.12 \pm 0.15^{\mathrm{a}}$ & $5.68 \pm 0.29^{\mathrm{b}}$ & $4.30 \pm 0.83^{\mathrm{bc}}$ & $3.46 \pm 0.27^{\mathrm{c}}$ \\
\hline
\end{tabular}

All values are represented as mean \pm standard deviation. ${ }^{\mathrm{a}-\mathrm{c}}$ in the same row with different letters indicates that the results are significantly different $(p<0.05) .{ }^{1}$ SB, spent hens breast; BB, broilers breast; ST, spent hens thigh; BT, broilers thigh.

\subsection{Cooking Yield and Water Holding Capacity}

Figure 1 shows the cooking yield and WHC of the breast and thigh of spent hens and broilers. The cooking yields of the breast of spent hens (SB) and the thigh of spent hens (ST) were significantly lower than those of the breast of broilers (BB) and thigh of broilers (BT; $p<0.05)$. As the structure of the muscle becomes smaller during maturation, the muscle has less space to retain, that is, the WHC is lowered [24]. Therefore, in this study, it is also judged to have a low cooking yield in spent hen. Additionally, regardless of the two breeds, between the breast and thigh there are different values $(p>0.05)$. This is due to the higher fat content in the thigh, which is red meat, compared to the breast, thereby resulting in a high water-binding capacity. This is consistent with a previous report by Lee et al. [25] who found that a higher intramuscular fat content was associated with a higher cooking yield. van der Sman [26] reported that the application of a physical force, such as heat, caused protein degradation resulting in the release of water from inside the muscle fibers. Therefore, the chicken breast, which has a high protein content, showed a higher volume of water loss compared to the thigh.

WHC refers to the force with which meat holds onto water throughout all processes including transport, storage, and mechanical processes such as cutting, heating, and grinding [23]. WHC and the cooking yield showed similar patterns; WHC was significantly higher for BT than for SB and ST $(p<0.05)$. Although it is the same breast, it seems that spent hen lacks the ability to bind moisture compared to broiler under heating stress. A study found that the water absorption capacity of myofibrillar protein in chicken breast was superior to that of thigh [27]. Therefore, it seems that additional research is needed 
to increase the moisture content by using any moisture treatment. Cao et al. [28] reported an increase in WHC after an ultrasound-assisted enzymatic treatment. In another study, WHC was improved physico-chemically using bromelain enzyme [29].

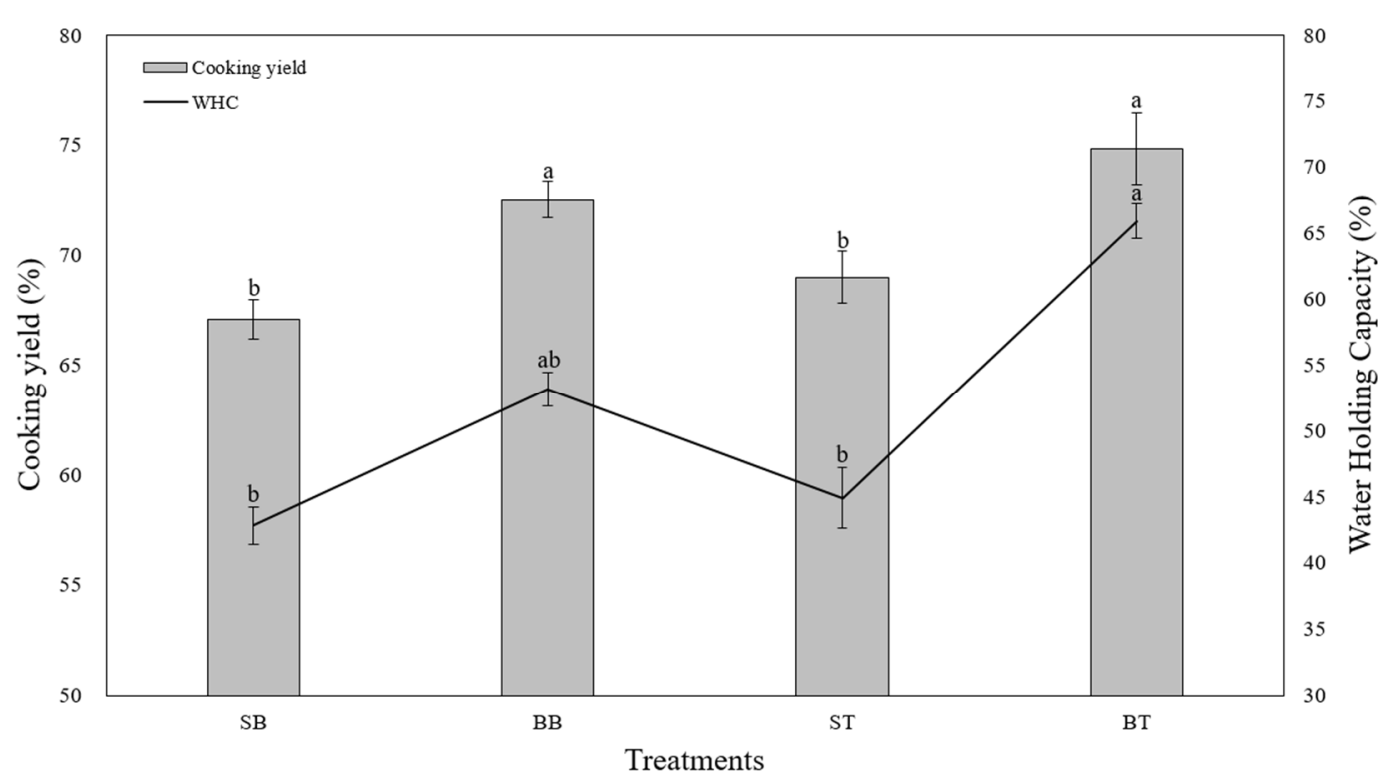

Figure 1. Cooking yield and WHC calculated from the breast and thigh of spent hens and broilers. Standard deviations are expressed on bars. $\mathrm{a}, \mathrm{b}$ in the same test with different letters indicates that the results are significantly different $(p<0.05)$. SB, spent hens breast; BB, broilers breast; ST, spent hens thigh; BT, broilers thigh.

\subsection{Shear Force}

Table 2 shows the shear force measurements for the breast and thigh of spent hens and broilers. SB showed a higher shear force than the other groups and a significantly higher shear force than BT $(p<0.05)$, due to the loss of moisture from myofibrils during cooking, which leads to a higher shear force [16]. This corroborates the results in the present study, which also demonstrated a decreasing shear force with higher WHC. This was similar to a report by Choe et al. [30] who demonstrated that breast meat was harder than thigh meat in Korean native chickens. In addition, Baéza et al. [31] reported that the fiber cross-sectional area hypertrophies as age increases, so it seems that the shear force of spent hens is high. Based on the findings in the present study, rather than using and selling SB, which has a high shear force, in its raw state, it would be better distributed as a processed product.

Table 2. Shear force in breast and thigh muscles from spent hens and broilers.

\begin{tabular}{ccccc}
\hline \multirow{2}{*}{ Traits } & \multicolumn{5}{c}{ Treatment $^{\mathbf{1}}$} \\
\cline { 2 - 5 } & SB & BB & ST & BT \\
\hline Shear force $(\mathrm{kg})$ & $3.41 \pm 0.17^{\mathrm{a}}$ & $3.29 \pm 0.24^{\mathrm{ab}}$ & $2.69 \pm 0.20^{\mathrm{ab}}$ & $2.54 \pm 0.28^{\mathrm{b}}$ \\
\hline
\end{tabular}

All values are represented as the mean \pm standard deviation. ${ }^{\mathrm{a}, \mathrm{b}}$ in the same row with different letters indicates that the results are significantly different $(p<0.05) .{ }^{1} \mathrm{SB}$, spent hens breast; BB, broilers breast; ST, spent hens thigh; BT, broilers thigh.

\subsection{Changes in Organoleptic Characteristics Detected Using Electronic Tongue}

Figure 2 shows the taste scores of the breast and thigh of spent hens and broilers which were analyzed using an electronic tongue. Sourness was the highest for SB at 8.5 and the lowest for ST at 3.2. Sourness was higher in the breast than in the thigh, irrespective of the type of chicken. Sourness in meat has been reported to be related to phenylalanine and isoleucine [32], and Chae et al. [33] reported that phenylalanine and isoleucine levels were higher in the breast than in the thigh, supporting the findings of the present study. The saltiness was 6.9 in ST and 5.6-5.8 in the other meats. Umami has been reported to be the 
fifth taste that can be perceived by humans, corresponding to the taste of monosodium glutamate and 5-ribonucleotides [34,35]. The umami score in BB and BT was 7.85, which was higher than the mean umami score in SB and ST (3.6). Glutamic acid is a free amino acid with the greatest effect on both saltiness and umami and has been reported to be present at higher levels in the thigh than in the breast [36]. Threonine, asparagine, and glycine have also been reported to affect the customer's preference, which is consistent with studies showing lower concentrations of these amino acids with increasing age [37]. The results of the present study showed that the thigh and breast meats were differentiated by sourness, whereas spent hens and broilers were differentiated by umami. Therefore, it would be advisable to add seasoning when processing spent hen meat to enhance its weak umami taste.

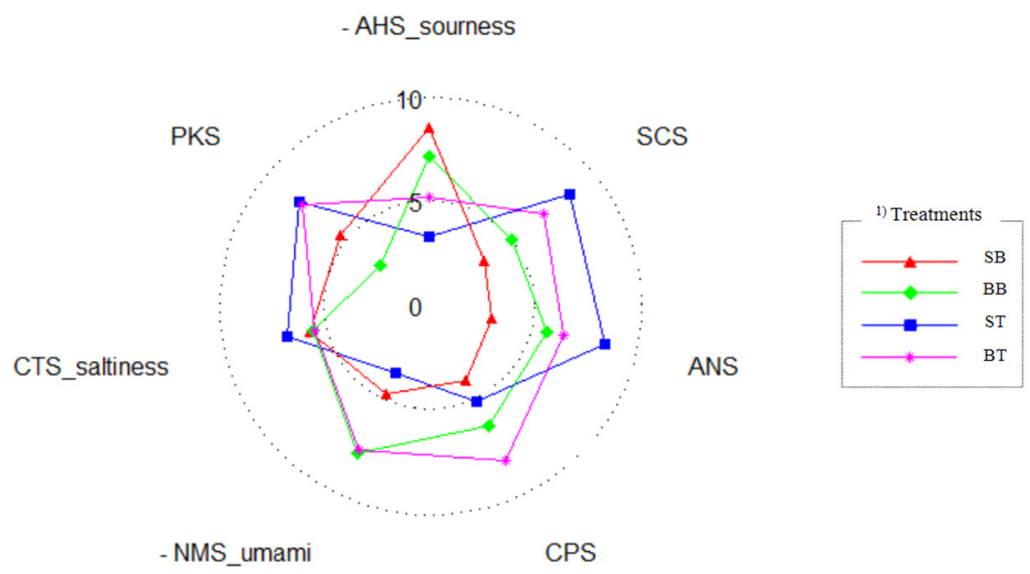

Figure 2. Changes in organoleptic characteristics detected using an electronic tongue on the breast and thigh of spent hens and broilers. SB, spent hens breast; BB, broilers breast; ST, spent hens thigh; BT, broilers thigh.

\subsection{Principal Component Analysis by Electronic Nose}

Figure 3 shows a comparison of aroma patterns between the breast and thigh of spent hens and broilers using PCA on data from an electronic nose. Previously, aroma patterns were determined using gas chromatography or gas chromatography-mass spectrometry. However, because these methods take a long time, electronic nose analysis is widely used at present [38]. The $X$-axis showed the largest variance, differentiating ST and BT (left of 0 ) from $\mathrm{SB}$ and $\mathrm{BB}$ (right of 0 ). The $Y$-axis showed the second largest variance, clearly differentiating SB and ST (above 0) from BT and BB (below 0). Compared to the electronic analysis, the $X$-axis was surmised to be affected by sourness, which distinguished between the breast and thigh, irrespective of the chicken type. Because the $Y$-axis distinguished between spent hens and broilers, it appeared to be affected by umami. In the graph, the breast formed small triangles while the thigh formed large triangles, which indicated that thigh meat included a large amount of connective tissue and that there was a large variance in aroma between different parts of the thigh. Overall, there was a clear separation of SB, $\mathrm{ST}, \mathrm{BB}$, and $\mathrm{BT}$ in the graph, indicating that each group had distinct aromas. 


\section{Discrimanation index $=96$}

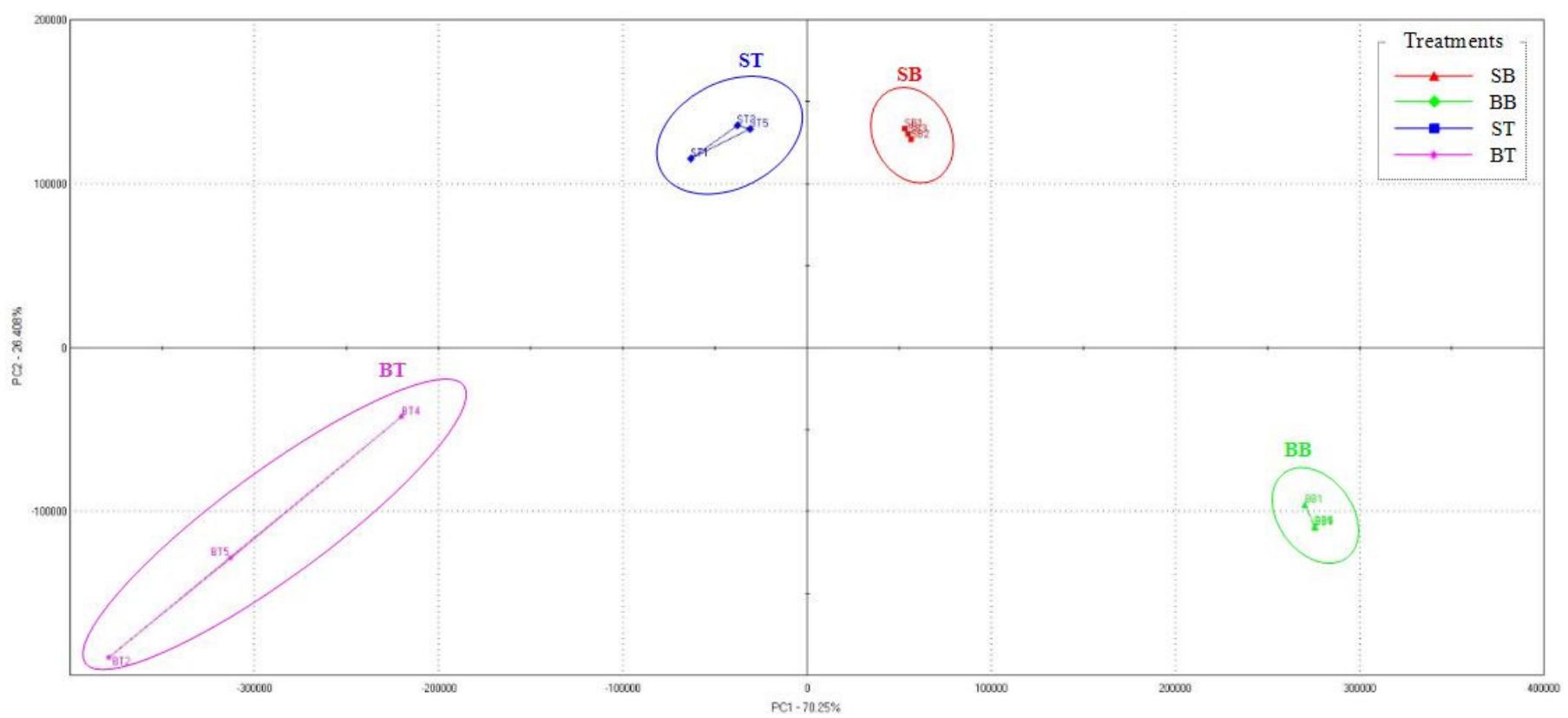

Figure 3. Principal component analysis using an electronic nose on the breast and thigh of spent hens and broilers. SB, spent hens breast; BB, broilers breast; ST, spent hens thigh; BT, broilers thigh.

\section{Conclusions}

As a result of this study, through an analysis of the quality and sensory characteristics of spent hens and broilers, we concluded the following. The color was the only difference between the breast and thigh; there was no other visual difference. The cooking yield was significantly different between the spent hens and broilers. The WHC was highest in the thigh of broilers when compared to other samples, but not significantly higher than the breast of broilers. The shear force was significantly higher in the breast of spent hens than in the thigh of broilers. Spent hens and broilers were significantly different according to the data collected using the electronic tongue and electronic nose. Consequently, there was a great difference in the parameters that affect palatability such as the cooking yield, WHC, and shear force. Thus, spent hen has a lower taste value than broiler, and processing spent hen is considered to require a pulverized meat product or flavor enhancer such as sodium glutamate, mono-sodium L-glutamate, etc.

Author Contributions: Conceptualization, S.-H.L. methodology, S.-H.L.; H.-Y.K. software, H.-Y.K. validation, S.-H.L. formal analysis, S.-H.L. investigation, H.-Y.K. resources, S.-H.L.; H.-Y.K. data curation, S.-H.L. writing — original draft preparation, H.-Y.K. writing—review and editing, S.-H.L.; H.-Y.K. visualization, S.-H.L.; H.-Y.K. supervision, H.-Y.K. project administration, S.-H.L.; H.-Y.K. funding acquisition, H.-Y.K. All authors have read and agreed to the published version of the manuscript.

Funding: This research was supported by Basic Science Research Program through the National Research Foundation of Korea (KRF) funded by the Ministry of Education (2018R1D1A1B07049938) and Mars Korea Co., Ltd. And this work was supported by the research grant of the Kongju National University in 2021.

Institutional Review Board Statement: Not applicable.

Data Availability Statement: Not applicable.

Conflicts of Interest: The authors declare no conflict of interest. 


\section{References}

1. Ham, Y.H.; Kim, S.I.; Lee, K.H. Effect of daily protein allowances during lay on egg production and feed cost of broiler breeders. Korean J. Poult. Sci. 2003, 30, 101-106.

2. Kang, H.K.; Kim, C.H. Effects of regulate in feed intakes on performance and meat quality in old laying hen. Korean J. Poult. Sci. 2015, 42, 205-214. [CrossRef]

3. Lee, Y.J.; Kim, C.J.; Park, B.Y.; Seong, P.N.; Kim, J.H.; Kang, G.H.; Kim, D.H.; Cho, S.H. Warner-Bratzler shear force, sarcomere length, total collagen contents and sensory characteristics of Hanwoo beef (Korean native cattle) quality grade. Korean J. Food Sci. Ani. Resour. 2009, 29, 726-735. [CrossRef]

4. Park, G.B.; Lee, J.I.; Jin, S.K.; Moon, J.D.; Shin, T.S. Changes in protein extractability, thiobarbituric acid and volatile basic nitrogen of spent layer meat treated with sodium chloride and phosphates. Korean J. Poult. Sci. 1994, 21, 249-256.

5. Park, O.J.; Kim, N.Y.; Han, M.J. The effect of jujubi, ginseng and garlic on the TBA value and microbial count of Samgaetang during refrigerated storage. Korean J. Soc. Food Cook Sci. 2003, 19, 591-595.

6. Hamm, D. Amino acid composition of breast and thigh meat from broilers produced in four locations of the united states. J. Food Sci. 1981, 46, 1122-1224. [CrossRef]

7. Korean Statistical Information Service. Slaughter Record by Chicken Breed. Available online: https://kosis.kr/statHtml/ statHtml.do?orgId=114\&tblId=DT_114_2016_S0023\&conn_path=I2 (accessed on 16 August 2021).

8. Kang, H.K.; Kim, J.H.; Hwangbo, J.; Kim, C.H. Effects of dietary supplementation of vitamin C and sea buckthorn on the performance and meat quality in old laying hen. Korean J. Poult. Sci. 2015, 42, 181-189. [CrossRef]

9. Korea Meat Trade Association (KMTA). Consumption Status of Chicken at Consumption Per Person (Kg). Available online: www.kmta.or.kr/kr/data/stats_spend.php (accessed on 30 October 2020).

10. Park, S.Y.; Kim, H.Y. Fried pork loin batter quality with the addition of various dietary fibers. J. Anim. Sci. Technol. 2021, 63, 137-148. [CrossRef]

11. Suwonsichon, S. The importance of sensory lexicons for research and development of food products. Foods 2019, 8, 27. [CrossRef] [PubMed]

12. Ruiz-Capillas, C.; Herrero, A.M.; Pintado, T.; Delgado-Pando, G. Sensory analysis and consumer research in new meat products development. Foods 2021, 10, 429. [CrossRef]

13. di Natale, C.; Paolesse, R.; Macagnano, A.; Mantini, A.; D’Amico, A.; Legin, A.; Lvova, L.; Rudnitskaya, A.; Vlasov, Y. Electronic nose and electronic tongue integration for improved classification of clinical and food samples. Sens. Actuators B 2000, 64, 15-21. [CrossRef]

14. Park, S.Y.; Kim, H.Y.; Choe, J. Application of an electric field refrigeration system on pork loin during dry aging. Food Sci. Anim. Resour. 2019, 39, 668. [CrossRef]

15. Lee, H.J.; Choe, J.; Kim, M.; Kim, H.C.; Yoon, J.W.; Oh, S.W.; Jo, C. Role of moisture evaporation in the taste attributes of dry-and wet-aged beef determined by chemical and electronic tongue analyses. Meat Sci. 2019, 151, 82-88. [CrossRef] [PubMed]

16. Kang, K.M.; Lee, S.H.; Kim, H.Y. Quality properties of whole milk powder on chicken breast emulsion-type sausage. J. Anim. Sci. Technol. 2021, 63, 405. [CrossRef]

17. Jung, S.; Lee, H.; Hwang, H.; Lim, D.; Lee, C.; Jo, C. Influence of bone fracture incidence on the quality of pork semimembranous muscle. Korean J. Agric. Sci. 2015, 42, 125-129.

18. Ruusunen, M.; Puolanne, E. Reducing sodium intake from meat products. Meat Sci. 2005, 70, 531-541. [CrossRef] [PubMed]

19. Park, S.Y.; Byeon, D.S.; Kim, G.W.; Kim, H.Y. Carcass and retail meat cuts quality properties of broiler chicken meat based on the slaughter age. J. Anim. Sci. Technol. 2021, 63, 180-190. [CrossRef] [PubMed]

20. Baek, K.H.; Lee, S.G.; Utama, D.T.; An, B.K.; Lee, S.K. Meat qualities and functional properties of broilers and spent layers slaughtered at different ages. Korean J. Poult. Sci. 2017, 44, 41-49. [CrossRef]

21. Kim, J.A.; Cho, E.S.; Jeong, Y.D.; Choi, Y.H.; Kim, Y.S.; Choi, J.W.; Kim, J.S.; Jang, A.; Hong, J.K.; Sa, S.J. The effects of breed and gender on meat quality of Duroc, Pietrain, and their crossbred. J. Anim. Sci. Technol. 2020, 62, 409-419. [CrossRef]

22. von Lengerken, G.; Maak, S.; Wicke, M. Muscle metabolism and meat quality of pigs and poultry. Vet. Ir. Zootech. 2002, 20, 82-86.

23. Kadığlu, P.; Karakaya, M.; Unal, K.; Babaoğlu, A.S. Technological and textural properties of spent chicken breast, drumstick and thigh meats as affected by marinating with pineapple fruit juice. Br. Poult. Sci. 2019, 60, 381-387. [CrossRef]

24. Huff-Lonergan, E.; Sosnicki, A. Water-holding capacity of fresh meat. Fact Sheet. 2002, 4669, 1-8.

25. Lee, Y.J.; Kim, C.J.; Park, B.Y.; Seong, P.N.; Kim, J.H.; Kang, G.H.; Kim, D.H.; Cho, S.H. Chemical composition, cholesterol, trans-fatty acids contents, $\mathrm{pH}$, meat color, water holding capacity and cooking loss of (Korean native cattle) quality grade. Korean J. Food Sci. Anim. Resour. 2010, 30, 997-1006. [CrossRef]

26. van der Sman, R.G.M. Model for electrical conductivity of muscle meat during Ohmic heating. J. Food Eng. 2017, 208, 37-47. [CrossRef]

27. Careri, M.; Mangia, A.; Barbieri, G.; Bouoni, L.; Virgili, R.; Parolari, G. Sensory property relationship to chemical date of Italian type dry-cured ham. J. Food Sci. 1993, 58, 968-972. [CrossRef]

28. Cao, C.; Xiao, Z.; Tong, H.; Tao, X.; Gu, D.; Wu, Y.; Xu, Y.; Ge, C. Effect of ultrasound-assisted enzyme treatment on the quality of chicken breast meat. Food Bioprod. Process. 2021, 125, 193-203. [CrossRef]

29. Kim, I.S.; Jang, A.; Jin, S.K.; Lee, M.; Jo, C. Effect of marination with mixed salt and kiwi juice and cooking methods on the quality of pork loin-based processed meat product. J. Korean Soc. Food Sci. Nutr. 2008, 37, 217-222. [CrossRef] 
30. Choe, J.H.; Nam, K.; Jung, S.; Kim, B.; Yun, H.; Jo, C. Differences in the quality characteristics between commercial Korean native chickens and broilers. Korean J. Food Sci. Anim. Resour. 2010, 30, 13-19. [CrossRef]

31. Baéza, E.; Arnould, C.; Jlali, M.; Chartrin, P.; Gigaud, V.; Mercerand, F.; Durand, C.; Méteau, K.; Le Bihan-Duval, E.; Berri, C. Influence of increasing slaughter age of chickens on meat quality, welfare, and technical and economic results. J. Anim. Sci. 2012, 90, 2003-2013. [CrossRef] [PubMed]

32. Xiong, Y.L.; Brekke, C.J. Changes in protein solubility and gelation properties of chicken myofibrils during storage. J. Food. Sci. 1989, 54, 1141-1146. [CrossRef]

33. Chae, H.S.; Choi, H.C.; Na, J.C.; Kim, M.J.; Kang, H.K.; Kim, D.W.; Kim, J.H.; Jo, S.H.; Kang, G.H.; Seo, O.S. Effect of raising periods on amino acids and fatty acids properties of chicken meat. Korean J. Poult. Sci. 2012, 39, 77-85. [CrossRef]

34. Yamaguchi, S.; Ninomiya, K. Umami and food palatability. J. Nutr. 2000, 130, 921S-926S. [CrossRef] [PubMed]

35. Dermiki, M.; Mounayar, R.; Suwankanit, C.; Scott, J.; Kennedy, O.B.; Mottram, D.S.; Gosney, M.A.; Blumenthal, H.; Methven, L. Maximising umami taste in meat using natural ingredients: Effects on chemistry, sensory perception and hedonic liking in young and old consumers. J. Sci. Food Agric. 2013, 93, 3312-3321. [CrossRef]

36. Wattanachant, S.; Benjakul, S.; Ledward, D.A. Composition, color, and texture of Thai indigenous and broiler chicken muscles. Poult. Sci. 2004, 83, 123-128. [CrossRef]

37. Ahn, D.H.; Park, S.Y. Studies on components related to taste such as free amino acids and nucleotides in Korean chicken meat. J. Korean Soc. Food Sci. Nutr. 2002, 31, 547-552.

38. Wojnowski, W.; Kalinowska, K.; Majchrzak, T.; Płotka-Wasylka, J.; Namieśnik, J. Prediction of the biogenic amines index of poultry meat using an electronic nose. Sensors 2019, 19, 1580. [CrossRef] [PubMed] 